\title{
The Caring Relationship
}




\title{
The Caring Relationship
}

\section{Elderly People and their Families}

\author{
Hazel Qureshi
}

Alan Walker

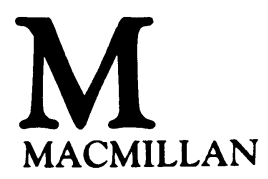


(C) Hazel Qureshi and Alan Walker 1989

All rights reserved. No reproduction, copy or transmission of this publication may be made without written permission.

No paragraph of this publication may be reproduced, copied or transmitted save with written permission or in accordance with the provisions of the Copyright, Designs and Patents Act 1988, or under the terms of any licence permitting limited copying issued by the Copyright Licensing Agency, 90 Tottenham Court Road, London W1P 9HE.

Any person who does any unauthorised act in relation to this publication may be liable to criminal prosecution and civil claims for damages.

First published 1989 by

THE MACMILLAN PRESS LTD

Houndmills, Basingstoke, Hampshire RG21 2XS

and London

Companies and representatives

throughout the world

ISBN 978-0-333-41948-9 ISBN 978-1-349-20264-5 (eBook)

DOI 10.1007/978-1-349-20264-5

A catalogue record for this book is available

from the British Library.

Reprinted 1993 
To the elderly people and their relatives who gave us their time so generously 


\section{Contents}

List of Tables and Figure viii

Preface $\mathbf{x}$

1 Introduction 1

2 Family Care and the State 15

3 Elderly People and their Families 33

4 The Need for Care 69

5 Patterns of Caring 113

6 Exchange, Reciprocity and Affect 145

7 Disability and Dependency 171

8 Formal and Informal Sources of Care 203

9 Conclusion: Towards Shared Care? 243

Appendix: Methodology 273

Bibliography 276

Index 288 


\section{List of Tables and Figure}

Tables

1.1 Numbers of elderly people in Great Britain 1901-2021 (000s)

1.2 Comparison of achieved sample with census data 9

3.1 Relatives listed by elderly people 34

3.2 Elderly people and their children $\quad 35$

3.3 Percentage of elderly people living in different types of household

3.4 Percentage of elderly people living in different types of joint household

3.5 Frequency of contact between different groups of elderly people and their children

3.6 Patterns of visiting by relatives 58

4.1 Percentage of elderly people requiring care 75

4.2 Need for and receipt of assistance with various activities

4.3 Percentage of elderly people receiving different amounts of care

4.4 Percentage of elderly people receiving care from different sources

4.5 Percentage of elderly people needing but not receiving any or enough care and tending

5.1 Sources of informal care for elderly people

5.2 Capacity of the model to predict principal carers (percentages)

5.3 Prediction of one-person principal carers (percentages)

5.4 Assistance given by work status (daughters-in-law of disabled elderly people) 
5.5 Choices between available daughters: percentage of daughters who were principal helpers by employment status

5.6 Choices between daughters: percentage of daughters who were principal helpers by marital status

6.1 Percentage of elderly men and women expressing particular closeness to people inside and outside their families

6.2 Percentage of carers who regarded themselves as emotionally close to the elderly person being cared for

6.3 Comparison of past and present relationship by carers (percentages)

6.4 Comparison of views of elderly people and their carers about the impact of helping on closeness

7.1 To whom elderly people turned if they felt low or if they had good news (percentages)

7.2 Carers' attitudes to residential care

8.1 Receipt of services by household type (percentages)

A.1 Original and achieved samples of elderly people

A.2 Original and achieved samples of carers

A.3 Percentage of elderly people receiving care from outside the household according to household type

\section{Figure}

5.1 Selection of relative(s) to provide practical assistance: flow chart to show decision-making process 


\section{Preface}

This book is about elderly people and their families. Although it has a particular focus upon the care given to elderly people in case of disability or other need, and is thus perforce largely about family care, it will be obvious that we would disown any inference that disability and dependency is the inevitable lot of those who achieve old age, or that becoming a 'burden' is the most likely consequence. The majority of people aged over 74 in the study we report led full and independent lives, and many others were better seen as interdependent than dependent.

The book begins with a description of the overall sample of elderly people, and goes on to discuss the patterns of contact which they have with their relatives and the variety of needs and sources of help which are identified. The second half of the book focuses upon those who receive regular assistance with practical tasks and discusses how choices are made about who will help within the family, what effects increasing disability and dependency are seen to have on relationships, and how statutory help is seen in relation to family help. We conclude with a discussion of the ways in which our improved knowledge of the informal sector might be better taken into account in the policy and practice of the formal sector of care. The policies of central and local government on pensions, benefits, housing, transport, health and social services all set the context in which exchanges of care within the family take place, but it is the services provided by the last of these which seem most often to be considered to be a possible substitute for family care.

The evidence we advance is based on a survey of around 300 people aged 75 or more, living in the community in Sheffield in $1982 / 3$, and follow-up interviews with some informal carers. The 
elderly people interviewed were a representative sample drawn with the help of the Sheffield Family Practitioner Committee's central age/sex register. We are grateful to the staff of the Family Practitioner Committee (FPC) and to the Sheffield GPs who cooperated with us.

We are aware that the restriction to one geographical area places limits upon the generalisability of the detail of our results. However, we see no reason to believe that families in Sheffield are greatly unlike families in other British cities. Readers will be aware that Sheffield has a reputation for a prevailing political commitment to collectively provided services coupled, as will become clear, with a widespread traditional view of family responsibilities.

Many people contributed to the successful implementation of the research. In particular, we wish to acknowledge the invaluable contribution of the other individuals who were at various times members of the research team: Josephine Green and Ken Simons who played important parts in the study of carers and in computing and data processing; Eileen Austin, Barbara Bell, Jean Bloor, Margaret Harrison and Nancy Pavey who undertook much of the interviewing of elderly people; and Margaret Jaram and Gloria Walton who were project secretaries. Margaret Jaram was primarily responsible for preparing the manuscript for publication. Nigel Johnson (on an Economic and Social Research Council linked studentship) and Mick Bond (on placement from the University of Surrey) also contributed to the research effort.

The research was funded by the Joseph Rowntree Memorial Trust and a special debt of thanks is owed to the then Director of the Trust, Robin Guthrie, who provided help and support considerably beyond that normally expected from funding agencies. Valuable advice and support were also received from Michael Bayley, Ron Middlestorb and Eric Sainsbury.

The research on which this book is based represented the fulfilment of a long-standing personal ambition for Alan Walker. His desire to conduct an enquiry into the family system of care stemmed both from his practical experiences in working with elderly people as part of his secondary school task force and the early years of his research career spent analysing data on elderly people from Peter Townsend's survey of household resources and living standards. This commitment was reinforced by 


\section{xii Preface}

his subsequent disappointment with the lack of penetration of sociological research on elderly people into the field of social policy (with the notable exception of the pioneering work of Peter Townsend). Hazel Qureshi came to the project, as Research Officer, from a background in social work and research into the community care of elderly people.

Alan Walker thanks Carol, Alison and Christopher for bearing so stoically the sacrifices necessary for the completion of this book. Hazel Qureshi thanks Martin and Imran for emotional support and distraction.

Our final and warmest thanks go to the elderly people and their carers who gave up their time to be interviewed and received us with such courtesy and friendliness. We hope that this book is a worthy reflection of their views.

Manchester

Sheffield
Hazel QuReshi

Alan Walker 